\section{From Marginality to Possibility: Doing Transgender Studies in Japanese Studies}

\section{SHU MIN YUEN}

National University of Singapore

(D) https://orcid.org/0000-0002-0485-2206

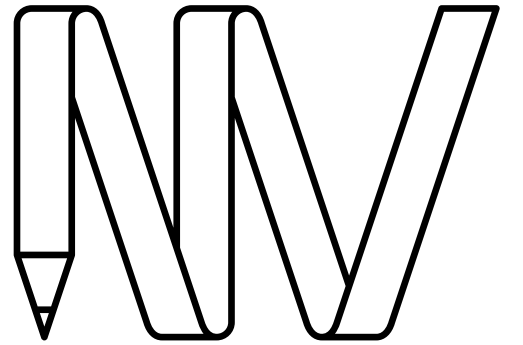

NEW

VOICES

IN JAPANESE STUDIES

\section{ABSTRACT}

Area studies has been described as having lost its significance and legitimacy in the 21st century globalised world. However, research has shown that the strengths of area studies-empirical research and context-sensitive knowledge-remain relevant not only in helping us to understand our contemporary world, but also in challenging the hegemony of theories and concepts developed in Euro-American contexts that have come to dominate both academic and general writing. In this paper, I draw on my research on the transgender community in Japan-an area of study that is relegated to the margins of both Japanese studies and trans studies - to show how the tools of area studies play an important role in expanding the conceptual boundaries of trans studies, and how the lens of transgender can expand or complicate existing knowledge on the culture and society of Japan. I highlight how Japanese transgender identities and cultures are shaped not only by global processes, but also legal, medical, cultural and social conditions specific to Japan. I argue against the assumed universal applicability of Eurocentric conceptualisations of gender/sexual non-conformity, and in doing so I call attention to the ways in which the fields of transgender studies and Japanese studies can enrich each other. More than ever in these precarious times, we need to emphasise the strengths and overcome the weaknesses of our field(s), so that we may be better equipped to turn marginality into possibility.

\section{KEYWORDS}

area studies; contemporary; FTM; gender; human rights; Japanese studies; law; marriage; queer; queer asian studies; sexuality; transgender
JAPANFOUNDATION \&

BRINGING JAPAN TO YOU

To link to this article:

https://doi.org/10.21159/nvjs.13.01

ISSN 2205-3166

New Voices in Japanese Studies is an interdisciplinary, peer-reviewed journal showcasing the work of emerging scholars with ties to Australia or New Zealand and research interests in Japan.

All articles can be downloaded free at newvoices.org.au

(c) The Japan Foundation, Sydney and Shu Min Yuen, 2021.

\section{(c)} cc) $\$$

This work is licensed under a Creative Commons Attribution-NonCommercialNoDerivatives 4.0 International License. 


\section{INTRODUCTION}

A s a Japan specialist based in a Japanese Studies department in a university in Asia, I am frequently asked by my peers based in social science disciplines about the future of my department, and by extension, my career. Given the drastic decline of area studies and Asian Studies in North American, Western European and Australian universities since the 1990s, their concerns are not unwarranted. Area studies was institutionalised at universities in the United States during the Cold War years to support US military and political needs, and is frequently criticised for being essentialist, descriptive and neo-imperialist. In the post-Cold war era, area studies has, according to some, increasingly become "a second-class enterprise in the university context" (Chua et al. 2019, 45) that is hopelessly caught in a vicious cycle of decreased funding, dwindling student numbers and loss of "academic legitimacy" (32).

The precarity of my academic career, however, results not only from the (perceived) declining relevance of area studies in the 21st century academy, but also from the marginal status of the subject of my study-trans and queer in Japan-within Japanese/area studies. ${ }^{1}$ I remember feeling awkwardly out of place at a literature panel that I was assigned to at a major international conference on Asian Studies several years ago-my paper was on the representation, embodiment and practices of transgender masculinity based on my ethnographic fieldwork in the trans male community in Tokyo, while the works of my fellow panellists, all literary scholars, did not deal at all with gender or sexuality. While this may have been a slip-up on the part of the conference organisers, I could not help but agree with what Howard Chiang, Todd Henry and Helen Leung observe:

"although scholars and activists have begun to examine long-standing histories and the politically engaged nature of trans cultures across the diverse societies of Asia over the past two decades [...] such work remains at the margins of Asian studies, rather than receiving the spotlight."

(Chiang et al. 2018, 298) ${ }^{2}$

If studies on trans and queer lives are marginalised in area studies, the reverse is also true: the focus of queer/trans studies has mainly been on North American and Western European societies (Jackson et al. 2005, 299). Even when queer lives in Asia are addressed, they tend to be studied as local phenomena to be explained by Euro-American theoretical paradigms (Chu and Martin 2007, 483). However, as Huso Yi reminds us, "caution must be used both in attempts to globalize US-dominant concepts of minority, and attempts to project modern, western notions of homosexuality into regions where these notions are inappropriate" (Yi 2005, 308).

1 I use the terms 'trans' and 'transgender' interchangeably to refer to people whose gender identity differs from the sex they were assigned at birth. Queer is used here as an umbrella term for non-normative configurations of gender and sexuality, as well as in a deconstructive sense to refer to practices and positionalities that may have the potential to destabilise or challenge normative ways of being and knowing. 
Although area/Japanese studies may be "struggling" (Ting 2020, 69) to maintain its relevance in today's academy-some have even suggested eradicating it entirely (see for example Chua et al. 2019; Chow 2002) -as Gavin Walker and Naoki Sakai remind us, the end of area (in the sense of "schema area" or "regime area") does not mean "the end of the importance of specific knowledge, linguistic study, or historically particular circumstances" $(2019,20)$. Working at the margins-and intersection-of area studies and trans/queer studies, I am constantly reminded that area studies is 'passé' and that research on queer in Japan has little value. I find solace and inspiration in the works of scholars researching gender and sexual non-normativity in Asia. These scholars, even if they do not necessarily identify as areaists, have recognised the significance of and used the tools of area studies to intervene in the exclusion of Asian queer lives in both queer studies and Asian studies (see for example Jackson 2000, 2001; Martin and Ho 2006; Sinnott 2004; Chiang 2012; McLelland 2005). By focusing on the historical, linguistic and cultural specificities of queer Asian lives, these works demonstrate how nonnormative gender and sexual identities and cultures in the Asian region have been variously shaped by local histories, as well as the legal, medical, cultural and social conditions specific to each location/culture. In so doing, they "resisted situating developments taking place across the societies in [...] Asia in terms of western developmental narratives" (McLelland 2018, 1273), and contributed to a reorientation of how scholars think and write about non-normative gender and sexual configurations, embodiments and practices in ways that de-privilege paradigms developed in North American and Western European contexts.

If the context-sensitive insights into the power formations, cultural expressions, social structures and processes of societies provided by area studies can contribute to a "deparochializ[ing] of US- and Euro-centric visions of the world in the core social science and humanities disciplines, among policy makers, and in the public at large" (Szanton 2002, 2), then trans/queer perspectives will also enrich area studies by bringing to the fore new issues and ways of thinking that area studies has traditionally overlooked. As pointed out by some, area studies, which takes an area and its population as the object of its inquiry, has a tendency to over-emphasise the fixity and coherence of an area when "the stability and continuity of culture areas and their diverse populations [have, in fact, been] held together in tenuous ways and through struggles that have privileged the interests of majority populations [...] at the expense of marginalized others" (Chiang et al. 2018, 299-300). The recently published edited volume Queer Korea (Henry 2020) shows us one way in which this shortcoming of area studies can be overcome. The chapters highlight how "practices of non-normative sexuality and gender variance have been consistently ignored or thought away" in both popular thought and academic writing in Korea (8). In accounting for these overlooked aspects of Korean society and history, the book contributes to a queering of the "nationalistically heteronormative" Korean Studies (8), thus illustrating how queer approaches can contribute to destabilising the assumed coherence of an 'area'. 
The work by queer Asian studies scholars has shown, and continues to show, that there are possibilities in marginality, and that marginality can be turned into possibilities. In the following sections, I draw on my research in the trans community in Japan and offer some thoughts on how my experience working at/from the margins helped me re-think my approaches in the fields of Japanese studies and trans studies. In particular, I discuss how Japanese studies can help to re-orient how we conceptualise trans practices and embodiments, and how trans perspectives can not only enhance, expand and/or complicate existing knowledge on the culture and society of Japan, but also provide some hints as to how we can take Japanese studies beyond its current boundaries.

\section{RETHINKING TRANS THROUGH THE LENS OF JAPAN}

My research focuses on trans men, or efu-tii-emu (エフティーエム; the Japanese transliteration of the English term 'FTM' or 'female-to-male'; hereafter, 'FTM') in Japan. I explore how trans men experience and negotiate inclusion in a society that continues to marginalise those who do not or cannot conform to prevailing gender and sexual norms. ${ }^{3}$ During my fieldwork, which took place between 2013 and 2018, I visited numerous places and attended various events organised by and/or for trans men, predominantly but not exclusively in Tokyo. They included FTM bars, various businesses owned and run by FTM-identified people, drinking parties, matchmaking events, peer-support sharing sessions, outdoor picnics and barbeques, home parties and music promotion events for an FTM idol group. I also attended photoshoots sessions of Laph - the only FTM magazine in circulation in Japan today, and the key site of my fieldwork. Depending on the scale of the event, at each of these events, I met anywhere between twenty to more than a hundred trans men and their partners. ${ }^{4}$

As a non-Japanese and non-trans person, and given the lack of in-depth studies on trans people-and especially trans men-in Japan in Englishlanguage academic scholarship, prior to entering the field I could only form a mental picture of my would-be informants through the lens of trans and queer studies based in Euro-American contexts that were available at the time. I had assumed that these theories and concepts on trans and queer would also apply to trans men in Japan. It turned out that this was not the case. I assumed that my informants would be keen to celebrate their transness, and use it to fight against the rigid gender system in Japan; after all, queer is defined as "against the regimes of the normal" (Warner 1993, xxvi). As such, I was surprised when I found the bold statement “We are normal” (僕たちは

3 I am aware that many trans people in and outside of Japan may not identify with the term 'FTM', but almost all trans men (a term which I am using interchangeably with 'FTM') whom I met during my fieldwork referred to themselves and other trans men using this term.

4 My fieldwork in Japan was first conducted between January 2013 and January 2014; I subsequently made several trips back to Tokyo from June 2014 through 2019. In addition to conducting participant observation at social events organised by and for trans men, I also conducted in-depth interviews with twelve trans men between 2013 and 2014. While my position as a non-Japanese and non-trans researcher from an overseas university relegated me to the status of an outsider, the border between outsider and insider was never a clear one for me: my perceived foreignness to Japanese and trans culture actually eased my entry into the FTM scene, and spurred the eagerness among many of my informants to share some aspects of their culture (Japanese and/ or FTM) with me. My familiarity with the Japanese language and cultural practices further allowed me to quickly develop a rapport with my informants. I am, however, mindful that I can never speak of my informants' experiences from their position. 
フツウです) in the editorial of one of the issues of Laph (Akito 2010, 61), and when informant after informant told me that all they want is to get married, have children, and lead an 'ordinary life' just like any other Japanese man. I could not help but wonder, why was the producer of a queer media product desiring, and creating the desire for, normality, instead of questioning and dismantling 'normal'?

From my participant observation at various FTM social events, and from my analysis of back issues of Laph and Japanese trans autobiographies, I found out that most of my informants prefer to-and in fact can only afford tolive 'under-the-radar' as gender-normative, 'ordinary' men (legally and/or socially) in their everyday lives. While there certainly are trans individuals and activists in Japan who reject the state-endorsed medico-legal discourse of transgender (see below), and who live openly as gender non-conforming persons, most of my informants chose not to come out or only come out selectively about their trans backgrounds. The transgender masculinity that is represented in, endorsed and promoted by the FTM magazine Laph is also one that emphasises naturalness, averageness and 'ordinariness"' (for a more detailed discussion, see Yuen 2018).

However, my informants also do not deny their trans backgrounds or reject connections with the trans community. Many of my informants were quite happy to mention (to me and to their trans peers) their birth names and pass around photos of themselves in their sailor suit uniforms during their high school days. ${ }^{5}$ During the weekends or after work, they participate in social activities such as drinking parties that are organised by and for trans men, and in so doing, they carve out a space for themselves to live as trans, and for a sense of community and belonging to a collective sociality of FTM trans people without undermining their male public selves (for more, see Yuen 2020).

While many queer scholars have repeatedly emphasised the need to resist normativity and trouble the status quo-which influenced the way I had thought about trans people in Japan prior to entering the field-it remains a fact that in many parts of Asia where being openly queer is not an available option, normativity is something that gender/sexual non-conforming people need to negotiate and seek to achieve, rather than resist, in order to survive (Yau 2010). Todd Henry (2020), John Cho (2020) and Layoung Shin (2020) have noted that even with the advancement of the gay and lesbian movement in South Korea since the mid-1990s, many queer Korean people prefer to stay invisible in society by not visibly manifesting a queer identity and avoiding open participation in LGBTQ (lesbian, gay, bisexual, transgender, queer) advocacy activities. When measured against the Anglo-Western model of rights and visibility, South Korea may appear 'backward'. However, as Henry (2020) argues, in a society where homosexuality is still highly stigmatised, adopting the Euro-American form of out-and-proud politics is not a viable option for these queer Koreans. It can “endanger one's ability to please kin networks, maintain intimate relationships, and succeed (or even survive) in the labour market" (Henry 2020, 30). 
Similarly in Japan, prejudice and a general lack of public understanding of gender and sexual non-conforming people continue to limit the life choices of many trans people. Yet, my informants do not concern themselves with demanding rights or lobbying for the de-medicalisation of transgender, even though many other trans people do. The abovementioned choices and practices of living publicly as men and participating in the FTM scene privately are, as I realise after spending some time in the field, strategies that my informants adopt to gain self-validation, economic survival and social membership as both trans and men. To my informants, the fact of being trans does not eclipse the myriad of identities that they may have, including their identity as men (and vice-versa). Like their gay and lesbian counterparts in South Korea, living socially as gender-normative men and privately as trans, rather than actively engaging in rights-based activism, has been perceived by many Japanese trans men to be the best or only way to ensure their liveability and survival in mainstream Japanese society. This reveals a different narrative of FTM lives in Japan-an alternative transgender modernity that does not necessarily diffuse from or converge towards a Western narrative of progress that has visibility, rights and recognition as its end point.

As seen from the assumptions that I brought into the field, an uncritical application of Euro-American theoretical paradigms onto the Japanese context is problematic and even imperialist (by erasing other ways of knowing, doing and being trans). It can also create a "hierarchy of experiences and subjectivities" (Leung 2016, 435) with the West-constructed as more 'advanced' and 'progressive'-at the top. In fact, this can be observed in some English-language media reports and articles on the latest developments concerning Japan's gender and sexual minorities. For example, in a recent 84-page Human Rights Watch (2019) report on Japan's gender recognition law, the author emphasised that the law, which "rests on an outdated and pejorative notion that a transgender identity is a mental health condition" and which enforces sterilisation of trans people, is "abusive" (3) and "regressive" (11). The report makes an urgent call for Japan to reform its laws (including removing the requirement to undergo surgery before qualifying for legal gender change) to be in line with international human rights standards and best practices of "modern medicine" (8). This, in effect, creates an image of Japan as backward and pre-modern.

In Japan, gender reassignment surgery, or sex reassignment surgery (性別適 合手術 or SRS) as it is commonly called in Japan today, became recognised in 1996 as the legal and appropriate medical treatment for the condition of Gender Identity Disorder (GID), or 'seidōitsuseishōgai' (性同一性障害) in Japanese. ${ }^{6}$ In 2004, trans people gained the right to change their legal gender in the koseki family register (戸籍) under the "Exceptional Treatment Law for People with Gender Identity Disorder” (性同一性障害者の性別の取り扱い の特例に関する法案; hereafter, Exceptional Treatment Law) after completing

6 In Japan, GID is understood as a medical condition marked by a disjuncture between one's gender identity and one's biological sex. For more on the guidelines for the diagnosis and treatment of GID in Japan, see Nomiya et al (2011, 14-19), and Nihon seishin shinkei gakkai (2006). Regarding SRS, although the term 'sex reassignment' has come under critique for reinforcing the notion that the truth of one's gender lies in one's body/genitals, and is increasingly being replaced by 'gender reassignment', 'gender confirmation' or 'gender affirmation' in the anglophone sphere, it remains the dominant term in Japan for referring to the family of surgical procedures that trans people are required to undergo in order to change their legal gender. As such, while I acknowledge the problems with this term, in this article, I refer to sex reassignment rather than its more recent variants in light of the context of my discussion-that is, contemporary Japanese society. 
sex reassignment surgery and fulfilling a list of other conditions. ${ }^{7}$ Despite the international move towards de-pathologising transgender in recent years, Japanese law continues to insist on a GID diagnosis and sex reassignment surgery as the key requirement for legal gender change. One common critique of the situation in Japan is that Japan is the only G7 country that maintains such a stringent requirement, and as such, there is a crucial need for it to 'catch up' to the standards of other first-world countries. This stance is highly reminiscent of the "tradition-modernity split" that Grewal and Kaplan (2001) observed in their international study of sexuality, where "the United States and Europe are figured as modern and thus as the sites of progressive social movements, while other parts of the world are presumed to be traditional" (669).

While there are indeed limitations to the law and the medical model of GID upon which the law is based (I will elaborate on this in the next section), criticising Japan on the basis of its departure from so-called modern international standards (of human rights and medicine) may risk what Mark McLelland (2005) would call a "transcultural reductiveness"-that is, "a tendency to locate the sexual ideas and practices of 'other' societies along a continuum of sameness or difference from those of the west" (4). No doubt, understandings and articulations of LGBTQ in Japan are to some extent Western-inflected (Shimizu 2007). For example, 'seidōitsuseishōgai' is itself a term and concept translated from the English term 'Gender Identity Disorder', and the diagnostic criteria for seidōitsuseishōgai in Japan was adopted from the fourth edition of the Diagnostic and Statistical Manual of Mental Disorders (DSM-IV) published by the American Psychiatric Association. However, as illustrated by the assumptions that I had brought into the field at the beginning of my research, explaining, measuring and criticising Japanese trans experience and culture in the language of those in Euro-American contexts can end up privileging Euro-American sexual identities and cultures. In effect, Japanese trans people, their cultures and practices become (problematically) constructed as backward, outdated and in need of liberation. To overcome "Western hegemonic interpretations of queerness and of non-Western sexualities [and genders]" (Wilson 2006, n.p.), it is therefore crucial that anyone writing about trans people in Japan (in fact, in any culture) recognise the role of not only global processes, but also local histories, socio-cultural processes, and medical and legal conditions in the shaping of their identities, practices and communities.

The strict conditions, including enforced sterilisation, stipulated in the Exceptional Treatment Law have certainly attracted criticism, including from within Japan itself. However, as Japan's first trans female politician Aya Kamikawa (2007) highlights, the requirement that the trans person making the legal gender change has no children (commonly known as the 'no-child condition') was critical to the passage of the law as it was used to appease the conservative members of the leading Liberal Democratic Party (LDP) and the

\footnotetext{
7 Under the Exceptional Treatment Law, the following five conditions must be fulfilled before an individual can change their gender in the family register: (1) to be above twenty years old, (2) to be unmarried at the time of application, (3) have no child, (4) to be deprived of gonad or gonad function, (5) to have genitalia that resemble the sex to which they have been reassigned. The 'no-child condition' was the most opposed condition among trans people, and this regulation was eventually relaxed in 2008 to "no child below the age of 20". For details on the Exceptional Treatment Law, see Taniguchi (2006); Harima et al. (2007); Kamikawa (2007, 104-34); Suganuma et al. (2010, 419-37).
} 
opposition parties. ${ }^{8}$ For the conservative LDP members, the family register is an inviolable sacred document that is the source of "Japanese family values" (Kamikawa 2007, 113). These are the people who have repeatedly rejected the bill to revise the civil code to allow married couples to have separate last names, and it was these people that the lawmakers, lawyers and activists who campaigned for the passing of the law needed to convince. Without the nochild condition, and other conditions such as sex reassignment surgery and the requirement that applicants are not married at the point of application, the law would result in same-sex marriages and families with two fathers/ mothers. This is an outcome that would destabilise the heteronormative family and gender binary systems, and to which the conservative politicians would definitely object. From this brief backstory to the passing of the Exceptional Treatment Law, it is clear that any critique of the law needs to take the socio-political context of Japan into consideration, and not assume the universality of the transgender experience, nor draw conclusions on the basis of sameness or difference from so-called 'international standards'.

\section{RETHINKING JAPAN THROUGH THE LENS OF TRANS}

Just as area studies can enrich other disciplines-in this case, Japanese studies enriching transgender studies-our understanding of an area can also be enhanced by looking at the area through the lens of transgender. As Susan Stryker (2006) highlights in the first volume of The Transgender Studies Reader, the Foucauldian notion of "the insurrection of subjugated knowledges" (12) is one key methodological concern of transgender studies. For Stryker, the potential of transgender studies lies in its ability to recover both knowledges and subjective experiences of trans people, and in so doing, "recapture, for use in the present, a historical knowledge of particular structurations of power" (13). Following Stryker, in the rest of this article, I will show how the trans voices and experiences that I have unearthed in my research reveal a simultaneous recognition and regulation by the Japanese state of the transgender subject in the late 1990s/early 2000s. This finding can in turn bring to light the operations of neoliberal governmentality in the managing of gender/sexual difference and diversity in Japanese society-a topic that has largely been excluded from the discussion on diversity in Japan.

For a large part of its modern history, Japan has maintained a self-image of an ethnically, culturally and linguistically homogeneous nation. Not only has this discourse of monoculturalism and monoethnicity been reproduced and reinforced in national policies, senior politicians such as former prime ministers Yasuhiro Nakasone and Tarō Asō have also time and again publicly claimed that Japan is a homogenous country with no minorities (Burgess 2007). ${ }^{9}$ Such claims of monoculturality have resulted in the belief that (ethnic and cultural) differences do not belong in Japanese society, and that assimilation is the only alternative to exclusion (Chapman 2006, 91). 
In the 1990s and 2000s, an alternative to assimilation and exclusion emerged following rising claims of discrimination and injustice from ethnic minority groups, as well as the increasing presence of migrant workers in Japan. These culminated in an ostensible recognition of the country's diverse ethnic and social composition through tabunka kyōsei (多文化共生; 'multicultural co-existence'), a Japanese notion of multiculturalism that emphasises harmonious co-living between the Japanese and foreigners. On the one hand, the adoption of tabunka kyōsei policies appears to suggest a positive move towards a recognition and inclusion of difference in Japanese society. ${ }^{10}$ On the other hand, however, minorities, and only specific groups of minorities, are included and tolerated as 'others' who are expected to learn to co-exist in harmony with the Japanese (Chapman 2006; Chapple 2011; Kawabata and Yamamoto 2020). Significantly, tabunka kyōsei discourses focus mainly on foreigners or ethnic 'others'-in other words, on difference that has been constructed as coming from 'outside' of Japanese society. Meanwhile, 'internal' differences within Japanese society such as disability, gender variance and non-normative sexualities continue to remain excluded from the parameters of 'tabunka' (多文化; lit., 'many cultures') (Flowers 2012, 529). In this way, through the strategic inclusion of some differences in the name of harmonious co-existence, diversity is contained by the authorities.

The Japanese state's agenda of managing rather than "recognizing differences and the resulting tensions that are manifest in such contexts" (Chapman $2006,100)$ becomes especially apparent when we consider the simultaneous recognition and regulation of trans people via the Exceptional Treatment Law during this time of the 1990s/2000s. The Exceptional Treatment Law (passed in 2003 and promulgated in 2004), while signifying the Japanese state's recognition of trans people as 'ordinary' citizens who are deserving of rights, also acts as a means through which trans people are rendered governable. Under the law, the transgender subject is defined as one who suffers from the medical condition of GID and desires sex reassignment surgery to change their physical sex. These conditions, and a few others (as mentioned earlier), must be fulfilled before a trans person is allowed to change their legal gender in the family register, a powerful state apparatus that identifies, defines and documents people as legal subjects and citizens of the Japanese state. ${ }^{11}$ In the process of making trans people verifiable and thus governable, the law produces specific regulatory practices (psychiatric counselling, hormone therapy and sex reassignment surgery) that discipline potentially unruly "trans bodies and narratives into fixed and permanent states” (Repo 2019, 15).

Even if the state's understanding of trans may not necessarily reflect trans people's realities, it is only by conforming to the state's disciplinary practices that trans people become intelligible to the state and are permitted to become

10 In the late 1980s and 1990s, local governments, especially in municipalities with a high number of foreign residents, started engaging with the idea of 'tabunka kyōsei' by implementing various initiative to support their foreign residents. Some of such initiatives include creating enquiry hotlines in foreign languages, providing support and advice on living in Japan, and organizing multicultural events and activities. It was only in 2006 that the Ministry of Internal Affairs and Communications started promoting and supporting intercultural cohesion at the local level across the nation. In 2007, Miyagi prefecture was the first municipality to issue an Ordinance for the Promotion of Multicultural Society (多文化共生社会の形成の推進に関する条例), which obliges businesses and residents in the prefecture to provide their support in creating a "multicultural co-living society" (多文化共生社会) (Miyagi Prefectural Government 2021).

11 For more detailed discussion on the Japanese family register, see for example Krogness (2014). 
legitimate subjects (by having a proper/corrected record in the family register). This is illustrated by my informant Kazuma's (pseudonym used) experience in making up parts of his personal history so that he could receive the GID diagnosis he needed to live legally as a man:

"I had to indicate on the form 'when I started feeling this way' or 'when I began desiring to become a man' in order to get my hands on the diagnosis letter to support my application to change my gender in the family register [...] But for me, it wasn't a matter of at what age I started feeling this way. I had always been like that; or rather, I always thought I would grow up to be a man."

(Kazuma 2013)

Despite the gaps between the criteria and his experience, Kazuma was able to navigate the process and receive his GID diagnosis, granting him the legal right to change his gender on the family register. However, trans people who cannot or refuse to receive a GID diagnosis and/or undergo sex reassignment surgery, or whose gendered practices and embodiment fall outside of the binary of male and female, will continue to remain unaccounted for and be excluded from the rights and privileges that come with legal gender change.

Following the promulgation of the Exceptional Treatment Law, sexual diversity became listed in 2004 on the agenda of human rights education and enlightenment by the Ministry of Justice (MOJ; 法務省) and the Ministry of Education, Culture, Sports, Science and Technology (MEXT; 文部科学 省). ${ }^{12}$ However, the latter has made no move to formalise the teaching of sexual diversity in the classroom (Watanabe et al. 2011, 97). Such a handsoff approach towards human rights and diversity by the MOJ as well as other governmental bodies resonates with Timothy Amos' (2011) analysis of the government's stance towards the human rights of burakumin (部落 民; a historic group of social outcasts). As Amos highlights, at the level of the state's discourse, human rights is portrayed as something that should be learnt and nurtured "at home, at school and the workplace" (177). In other words, it is something that should be dealt and engaged with at the individual or everyday institutional level, rather than something that the state is responsible for. This most likely explains why sexual diversity and human rights were not, and will not, be formalised in the official school curriculum.

The government's tokenistic and cosmetic approach to recognising and including trans people in society is further revealed when we examine how the law affects the lives of trans people at the level of the everyday. My informant Kazuma, whom I mentioned earlier, recounted to me that he attempted to enrol in a healthcare-related certificate course at a vocational school multiple times, but was rejected because of his trans background. Despite having updated his official documents following his legal gender change, he was not 
able to change his given name as recorded on his university certificate, causing him to be outed as trans on occasions when his university certificate must be produced, such as when applying to the vocational school. As Kazuma points out,

"I graduated from a public university, and unlike private universities, public universities do not allow a name change on their certificates. Because of the nature of the course that I wanted to enrol in, the interviewers told me that it's going to be a problem if other students find out that I'm trans, and if that happens, the school will not be able to deal with it."

(Kazuma, 2013)

Kazuma's case further highlights the superficiality of the government's approach to dealing with trans issues in society. Although the government appears to recognise the gender identity of trans people through the Exceptional Treatment Law, the universities that it funds ironically do not allow transgender graduates to change their names on their certificates, causing their trans backgrounds to be traceable in records that, more often than not, work to their disadvantage, entrenching discrimination.

Thus, the recognition of transgender subjects by the state is simultaneously a regulation of gender variance that in turn brings about, and even encourages, new forms of exclusion. The narrowly defined nature of transgender subjectivity, and the stringent conditions that need to be met before a trans person can have their gender legally recognised presents a strong signal that there is no room for gender ambiguity in Japanese society. The lack of government support for sexual diversity and transgender human rights education further reveals the state's neoliberal stance in constructing exclusion or discrimination as an individual matter, especially for those who fail or choose not to conform to the traditional gender economy of male or female. On the surface, the Exceptional Treatment Law suggests a paradigm shift towards a liberal acceptance of gender variance in Japanese society. However, when we consider the normalising logic of the state's recognition of gender variance that comes intertwined with regulation, these are recast as a neoliberal agenda of social control and assimilation. Recognition, and the associated rights and privileges, while bringing about inclusion (as legal Japanese subjects via the family register), can also be a means of discipline and control, and even exclusion, for those who fail to conform to the 'correct' way of being trans. Examining the processes by which trans bodies are produced, disciplined and governed thus brings to light a complex situation. Trans people's struggles for validation as gendered subjects conflict with the state's attempt at containing the perceived threat of gender/sexual diversity-a situation that the current tabunka kyōsei discourse (including its critiques to date) has failed to capture. 


\section{CONCLUSION}

This paper was motivated partly by a desire to defend the academic legitimacy of Japanese studies, a field that I remain deeply passionate about despite its increasing marginalisation in the academy. However, I am by no means arguing for a return to an essentialist, neo-imperialist or homogenising way of understanding culture. As Morris-Suzuki (2019) observes, area studies has moved on from such 1950s-style way of conceptualising the world (213). My focus on the local and specific also does not represent an automatic rejection of global and transnational influences. Rather, my aim in this paper is to show how the tools of area studies play an important role in expanding the conceptual boundaries of trans studies, and how the lens of transgender can helpfully complicate existing knowledge on the culture and society of Japan. Probing into the less-often heard narratives and struggles of trans people (albeit a particular group of trans men predominantly located in Tokyo) in Japan has enabled me to see beneath the surface of a heteronormative and apparently culturally homogenous (recently more visibly multi-cultural) Japan that the Japanese state, social institutions and even some scholars have constructed and tried to sustain. My examination of how trans bodies are brought into subjectivity and simultaneously disciplined (through regulatory practices such as sex reassignment surgery) reveals how the Japanese state is invested in defining and categorising its population into male or female subjects to upkeep the heteronormative family and gender-binary system. Behind the seemingly liberal recognition and inclusion of trans people in Japanese society is, in fact, an attempt at managing and containing a perceived threat to social cohesion that gender transgression might bring. The desire among my informants to live as 'ordinary' men may be seen as a manifestation of such state control and regulation. Their shuttling between their public male selves and private FTM selves can also be seen as a strategy that they adopt to ensure economic and social survival in a culture that has yet to fully accept gender/sexual non-normativity.

From the perspective of Euro-American queer theory, my informants are likely to be seen as 'unqueer'. However, as I have tried to demonstrate in this article, an uncritical application of theories conceived in a different culture onto the Japanese context is most likely bound to fail. Even if concepts such as 'GID' and 'FTM' were originally borrowed from the United States, and even as some Japanese LGBTQ activists have embraced the language of rights, liberation, normalisation or antinormativity (rhetoric commonly used in North America and Western Europe) in their efforts to push for social change, we need to remember that there are many trans people in Japan (and elsewhere too) who "do not always rely on well-known logics of public visibility or espous[e] antinormative politics as their modus operandi" (Chiang et al. 2018, 300). As such, researchers should always consider the complex dynamics between global trends and locally situated socio-cultural and political conditions that have come to enable and limit the imaginations, articulations and lived realities of trans people in the areas/cultures that we study. And area studies, with its emphasis on empirical research and contextual knowledge, provides us with the tools to do just that. 
In her closing remarks to the virtual roundtable "The 'Rebirth' of Japanese Studies", Japan scholar Paula Curtis urges "members of a global Japanese Studies community" to rethink our profession and facilitate the rebirth of our field (2020, n.p.). When our position in the academy is pushed to the margins of the margins, what can we do, individually and collectively, to ensure the survival of our field and safeguard our livelihood? Perhaps it is in such precarious times that we need, more than ever, to emphasise the strengths and overcome the weaknesses of our field(s), as I have done in this article. We need to think beyond Japanese studies, both in the sense of engaging with other disciplines as well as breaking through the traditional, and at times problematic, way of doing Japanese studies. In doing so, I envisage we will be in a better position to turn marginality into possibility.

\section{ACKNOWLEDGEMENT}

I am very grateful to Gwyn McClelland, Elicia O'Reilly and the two anonymous reviewers for their invaluable feedback and thoughtful comments.

\section{APPENDIX: LIST OF INTERVIEWS}

Kazuma. 2013. Interview by author. Digital recording in Japanese.

November 23.

\section{GLOSSARY}

\section{burakumin (部落民)}

a historic group of social outcasts in Japan

\section{Exceptional Treatment Law}

Exceptional Treatment Law for People with Gender Identity Disorder (性同一 性障害者の性別の取り扱いの特例に関する法案); stipulates the conditions that must be fulfilled before an individual can change their gender in the family register in Japan

FTM (エフティーエム)

female-to-male transgender

GID

Gender Identity Disorder

koseki (戸籍)

family register

LDP

Liberal Democratic Party; a leading conservative political party in Japan 
MEXT

Ministry of Education, Culture, Sports, Science and Technology (文部科学省)

MOJ

Ministry of Justice (法務省)

no-child condition

a term used to refer to the requirement under the Exceptional Treatment Law for People with Gender Identity Disorder that a trans person making a legal gender change has no children

seidōitsuseishōgai (性同一性障害)

Gender Identity Disorder

SRS (性別適合手術)

used in Japan to mean gender reassignment surgery (from 'sex reassignment surgery')

tabunka kyōsei (多文化共生)

lit., 'multicultural co-existence'; a notion of multiculturalism that emphasises harmonious co-living between the Japanese and foreigners

\section{REFERENCES}

Akito, S. 2010. Laph. Print magazine, February issue.

Amos, T. 2011. Embodying Difference: The Making of Burakumin in Modern Japan. Honolulu: University of Hawai'i Press.

Burgess, C. 2007. "Multicultural Japan? Discourse and the 'Myth' of Homogeneity." Japan Focus: The Asia-Pacific Journal 5 (3). Accessed 15 January, 2021. https://apjjf.org/-Chris-Burgess/2389/article.html.

Chapman, D. 2006. "Discourses of Multicultural Coexistence (Tabunka Kyōsei) and the 'Old-Comer' Korean Residents of Japan.” Asian Ethnicity 7 (1): 89-102. https://doi.org/10.1080/14631360500498593.

Chapple,J.2011. "Exclusive Inclusion:Japan's Desire for, and Difficulty with, Diversity." In Citizens of the World: Pluralism, Migration and Practices of Citizenship, edited by D. Robert, 79-97. New York: Rodopi. https://doi.org/10.1163/9789 042032569_006.

Chiang, H. (ed.). 2012. Transgender China. New York: Palgrave Macmillan. https:// doi.org/10.1057/9781137082503.

Chiang, H., T. A. Henry and H. H. Leung. 2018. "Trans-in-Asia, Asia-in-Trans: An Introduction." TSQ: Transgender Studies Quarterly 5 (3): 298-310. https://doi.org/10.1215/23289252-6900682. 
Cho, J. 2020. "The Three Faces of South Korea's Male Homosexuality: Pogal, Iban, and Neoliberal Gay." In Queer Korea, edited by T. Henry, 263-94. Durham: Duke University Press. https://doi.org/10.1215/9781478003366-010.

Chow, R. 2002. "Theory, Area Studies, Cultural Studies: Issues of Pedagogy in Multiculturalism." In Learning Places: The Afterlives of Area Studies, edited by M. Miyoshi and H. Harootunian, 103-18. Durham and London: Duke University Press. https://doi.org/10.1215/9780822383598-005.

Chu, W. and F. Martin. 2007. "Editorial Introduction: Global Queer, Local Theories." Inter-Asia Cultural Studies, 8 (4): 483-84. https://doi.org/10.1080/1464937 0701567948 .

Chua B. H., K. Dean, H. Engseng, H. K. Chong, J. Rigg and B. Yeoh. 2019. "Area Studies and the Crisis of Legitimacy: A View from South East Asia." South East Asia Research 27 (1): 31-48. https://doi.org/10.1080/0967828X.2019. 1587931.

Cromwell, J. 1999. Transman and FTMs: Identities, Bodies, Genders, and Sexualities. Urbana: University of Illinois Press.

Curtis, P. 2020. “Virtual Roundtable: The 'Rebirth' of Japanese Studies." Paula R. Curtis. Accessed 30 July, 2021. http://prcurtis.com/events/AAS2020/.

Flowers, P. 2012. "From Kokusaikai to Tabunka Kyōsei: Global Norms, Discourses of Difference, and Multiculturalism in Japan." Critical Asian Studies 44 (4): 515-54. https://doi.org/10.1080/14672715.2012.738540.

Grewal, I. and C. Kaplan. 2001. "Global Identities: Theorizing Transnational Studies of Sexuality." GLQ: A Journal of Lesbian and Gay Studies 7 (4): 663-79. https://doi.org/10.1215/10642684-7-4-663.

Harima, K., T. Ōshima, A. Nomiya, M. Torai and A. Kamikawa [針間 克己、大島 俊 之、野宮 亜紀、虎井 まさ衛、上川 あや]. 2007. Puroburemu QઐA: Seidoitsu seishōgai to koseki-seibetsu henkō to tokureihōo kangaeru [プロブレム Q\&A: 性同一性障害と戸籍一性別変更と特例法を考える] Tokyo: Ryokufū Shuppan [緑風出版].

Henry, T. 2020. "Queer Korea: Toward a Field of Engagement." In Queer Korea, edited by T.Henry, 1-52. Durham: Duke University Press. https://doi. org/10.1215/9781478003366-001.

Human Rights Watch. 2019. “'A Really High Hurdle’: Japan's Abusive Transgender Legal Recognition Process." Human Rights Watch. Accessed 15 January, 2021. https://www.hrw.org/report/2019/03/19/really-high-hurdle/japans-abusivetransgender-legal-recognition-process.

Jackson, P. 2000. "An Explosion of Thai Identities: Global Queering and ReImagining Queer Theory." Culture, Health \& Sexuality 2 (4): 405-24. https:// doi.org/10.1080/13691050050174422. 
2001. "Pre-Gay, Post-Queer: Thai Perspectives on Proliferating Gender/Sex Diversity in Asia." In Gay and Lesbian Asia: Culture, Identity, Community, edited by G. Sullivan and P. Jackson, 1-25. New York: Harrington Park Press. https://doi.org/10.1300/J082v40n03_01.

Jackson, P., F. Martin, M. McLelland. 2005. “AsiaPacifiQueer: An Introduction.” In "Re-Placing Queer Studies: Reflections on the Queer Matters Conference (King's College, London, May 2004).” Inter-Asia Cultural Studies 6 (2): 299311. https://doi.org/10.1080/14649370500066035.

Kamikawa, A. [上川あや]. 2007. Kaete yuku yūki: 'Seidōitsuseishōgai' no watashi kara [変えてゆく勇気: 「性同一性障害」の私から]. Tokyo: Iwanami Shoten [岩波新書].

Kawabata, K. and N. Yamamoto. 2020. "Rethinking the Principles of 'Kyōsei' in Japan: Intersections Between Oldcomers and Newcomers." In Cultural and Social Division in Contemporary Japan: Rethinking Discourses of Inclusion and Exclusion, edited by Y. Shiobara, K. Kawabata and J. Matthews, 241-58. 1st edition. Abingdon and New York: Routledge. https://oi.org/10.4324/ 9781315143705-15.

Krogness, K. 2014. "Jus Koseki: Household Registration and Japanese Citizenship." In Japan's Household Registration System and Citizenship: Koseki, Identification and Documentation, edited by D. Chapman and K. J. Krogness, 145-65. New York and London: Routledge. https://doi.org/10.4324/97813 15889757-9.

Leung, H. 2016. "Always in Translation Trans Cinema across Languages." TSQ: Transgender Studies Quarterly 3 (3-4): 433-447. https://doi.org/10.1215/ 23289252-3545143

Martin, F. and J. Ho. 2006. "Editorial Introduction: Trans/Asia, Trans/Gender." InterAsia Cultural Studies 7 (2): 185-87. https://doi.org/10.1080/146493706006 73664.

McLelland, M. 2005. Queer Japan from the Pacific War to the Internet Age. Lanham: Rowman \& Littlefield Publishers.

. 2018. "From Queer Studies on Asia to Asian Queer Studies." Sexualities 21 (8): 1271-75. https://doi.org/10.1177/1363460718770448.

Miyagi Prefectural Government [宮城県]. 2021. “Tabunka kyōsei shakai no jitsugen [多文化共生社会の実現].” Miyagi Prefectural Government, April 1 [webpage]. Accessed 28 August, 2021. https://www.pref.miyagi.jp/site/tabunka/law.html.

MOJ (Ministry of Justice) [法務省] and MEXT (Ministry of Education, Culture, Sports, Science and Technology) [文部科学省]. 2004. White Paper on Human Rights Education and Enlightenment [人権教育・啓発白書]. Tokyo: Kokuritsu insatsu kyoku [国立印刷局].

Morris-Suzuki, T. 2019. "Liquid Area Studies: Northeast Asia in Motion as Viewed from Mount Geumgang." positions: asia critique 27 (1): 209-39. https://doi. org/10.1215/10679847-7251897. 
Nihon Seishin Shinkei Gakkai [日本精神神経学会]. 2006. “Seidōitsuseishōgai ni kansuru shindan to chiryōnogaidorain [性同一性障害に関寸る診断と治療のガ イドライン].” Accessed March 4, 2010. http://www.jspn.or.jp/ktj/ktj_k/pdf_ guideline/guideline-no3_2006_11_18.pdf.

Nomiya, A., K. Harima, T. Ōshima, T. Harashina, M. Torai and Y. Uchijima [野宮 亜 紀、針間 己、大島 俊之、原科 孝雄、虎井 まさ衛、内島 豊]. 2011. Puroburemu QઐA: Seidōitsuseishōgai tte nani? Hitori hitori no sei no ariyō o taisetsu ni suru tame [プロブレムQ\&A : 性同一性障害って何?一人一人の性のありようを大 切にするために]. Tokyo: Ryokufū shuppan [緑風出版].

Repo, J. 2019. "Governing Juridical Sex: Gender Recognition and the Biopolitics of Trans Sterilization in Finland." Politics and Gender 15 (1): 1-24. https:// doi.org/10.1017/S1743923X1800034X.

Shimizu, A. 2007. "Scandalous Equivocation: A Note on the Politics of Queer Self-Naming." Inter-Asia Cultural Studies 8 (4): 503-16. https://doi. org/10.1080/14649370701567963.

Shin, L. 2020. "Avoiding T'ibu (Obvious Butchness): Invisibility as a Survival Strategy among Young Queer Women in South Korea." In Queer Korea, edited by T. Henry, 295-322. Durham: Duke University Press. https://doi. org/10.1215/9781478003366-011.

Sinnott, M. 2004. Toms and Dees: Transgender Identity and Female Same-Sex Relationships in Thailand. Honolulu: University of Hawai'i Press.

Stryker, S. 2006. “(De)Subjugated Knowledges: An Introduction to Transgender Studies." In The Transgender Studies Reader, edited by S. Stryker and S. Whittle, 1-17. New York: Routledge.

Suganuma, K., H. Ishida and I. Sugiura. 2010. "Japan." In The Greenwood Encyclopedia of LGBT Issues Worldwide, edited by C. Stewart, 419-37. California: Greenwood Press.

Szanton, D. 2002. "Introduction: The Origin, Nature, and Challenges of Area Studies in the United States." In The Politics of Knowledge: Area Studies and the Disciplines, edited by D. Szanton, 1-33. Berkeley, Los Angeles and London: University of California Press.

Takahashi, Y. [高橋 裕子]. 2013. “Gakkō ni okeru taiō rei [学校における対応例].” In Seidōitsuseishōgai no iryō to hō-iryō, kango, hōritsu, kyōiku, gyōsei kankeisha ga shitteokitai kadai to taiō [性同一性障害の医療と法一医療、看 護、法律、教育、行政関係者が知っておきたい課題と対応], edited by C. Nōno [南野 智恵子], 349-58. Osaka: Medica [メディカ].

Taniguchi, H. 2006. "The Legal Situation Facing Sexual Minorities in Japan." Intersections: Gender, History and Culture in the Asian Context 12. Accessed 10 January, 2021. http://intersections.anu.edu.au/issue12/taniguchi.html.

Ting, E. G. 2020. "Negativity and Hope, or Addressing Gender and Race in Japanese Studies." Gender and Sexuality 15: 67-81. 
Walker, G. and N. Sakai. 2019. "The End of Area." positions: asia critique 27 (1): 1-31. https://doi.org/10.1215/10679847-7251793.

Warner, M. 1993. “Introduction.” In Fear of a Queer Planet: Queer Politics and Social Theory, edited by M. Warner, vii-xxxi. Minneapolis: University of Minnesota Press.

Watanabe, D., Y. Kusunoki, M. Tashiro and K. Ushitora [渡辺 大輔、楠 裕子、田代 美江子、艮 香織]. 2011. “Chūgakkō ni okeru 'sei no tayōsei' rikai no tame no jugyō dukuri [中学校における「性の多様性」理解のための授業づくり].” Journal of Integrated Center for Clinical and Educational Practice [教育実践 センター紀要] 10 (3): 97-104.

Wilson, A. 2006. "Queering Asia." Intersections: Gender, History and Culture in the Asian Context 14. Accessed 25 July, 2021. http://intersections.anu.edu.au/ issue14/wilson.html\#n1.

Yasuda, Y. [安田 洋平]. 2010. NHK ‘hāto o tsunagō' LGBT Book [NHK 「ハートをつな ごう」LGBT Book]. Tokyo: Ōta Shuppan [太田出版].

Yau, C. 2010. "Dreaming of Normal While Sleeping with Impossible: Introduction." In As Normal As Possible: Negotiating Sexuality and Gender in Mainland China and Hong Kong, edited by C. Yau, 1-14. Hong Kong: Hong Kong University Press. https://doi.org/10.5790/hongkong/9789622099876.003.0001.

Yi, H. 2005. "A Condition of Queerness at Queer Matters: Localizing Discourse at a 'Global' Conference." In "Re-Placing Queer Studies: Reflections on the Queer Matters Conference (King's College, London, May 2004)." Inter-Asia Cultural Studies 6 (2): 299-311. https://doi.org/10.1080/14649370500066035.

Yuen, S. M. 2018. "Mediated Masculinities-Negotiating the 'Normal' in the Japanese Female-to-Male Trans Magazine Laph." In Routledge Handbook of Japanese Media, edited by F. Darling-Wolf, 180-99. London and New York: Routledge. https://doi.org/10.4324/9781315689036-13.

2020. " Unqueer Queers-Drinking Parties and Negotiations of Cultural Citizenship by Female-to-Male Trans People in Japan.” Asian Anthropology 19 (2): 86-101. https://doi.org/10.1080/1683478X.2020.1756073. 